\title{
Spotlight on measles 2010: Measles outbreak among travellers returning from a mass gathering, Germany, September to October 2010
}

G Pfaff (guenter.pfaff@rps.bwl.de) ${ }^{1}$, D Lohr ${ }^{1}$, S Santibanez ${ }^{2}$, A Mankertz $^{2}$, U van Treeck ${ }^{3}$, K Schönberger $^{4}$, W Hautmann

1. Baden-Wuerttemberg State Health Office, District of Stuttgart Government, Stuttgart, Germany

2. National Reference Centre for Measles, Mumps and Rubella (NRC MMR), Robert Koch Institute (RKI), Berlin, Germany

3. NRW Institute of Health and Work, Düsseldorf, Germany

4. Bavarian Health and Food Safety Agency, Oberschleißheim, Germany

Citation style for this article:

Pfaff G, Lohr D, Santibanez S, Mankertz A, van Treeck U, Schönberger K, Hautmann W. Spotlight on measles 2010: Measles outbreak among travellers returning from a mass gathering, Germany, September to October 2010. Euro Surveill. 2010;15(50):pii=19750. Available online: http://www.eurosurveillance.org/

ViewArticle.aspx?Articleld $=19750$

Article published on 16 December 2010

In September and October 2010, 13 primary measles cases were identified among unvaccinated persons aged between 9 and 32 years (median: 16.5) in 11 districts in Germany. All cases had attended meetings in Taizé, France. This outbreak illustrates the risk of long distance spread of infectious diseases associated with international mass gatherings, and underlines the importance of closing immunisation gaps against measles by vaccinating non-immune adolescents and young adults.

\section{Introduction}

Reports on measles outbreaks in Europe point to the importance of travelling non-immune adolescents and young adults in spreading the disease. Measles outbreaks related to short commutes [1], intermediate, and long distance travel $[2,3]$ have been reported in the past. We describe an outbreak that affected predominantly adolescents and young adults who had recently participated in meetings in Taizé, France. Taizé is home to an ecumenical Christian community of Protestant and Catholic traditions, and is one of the most important sites of Christian pilgrimage. Meetings draw thousands of young people from around the world for contemplation, Bible study and communal work.

\section{Outbreak investigation}

Between 13 and 21 September 2010, public health authorities in the German Laender of BadenWuerttemberg and North Rhine-Westphalia received notifications of six measles cases in adolescents who had recently returned from meetings in Taizé, France. This was communicated in a public health notice in the German epidemiological bulletin [4] in order to alert the public health community, and to identify any additional cases. A case was defined as clinically diagnosed or laboratory-confirmed measles infection notified in September or October 2010 in a person who had recently travelled to Taizé. French authorities were informed about the outbreak by the Robert Koch
Institute via the Early Warning and Response System (EWRS). The Taizé Community was contacted via electronic mail, and designated a contact person who responded to emails and telephone calls with helpful information about the setting. All patients were contacted by local health authorities via telephone or in writing and were interviewed about their history of measles, immunisation with measles virus-containing vaccine, and details of travel and accommodation, where available. Diagnostic confirmation of cases was sought by laboratory detection of measles virus-specific IgM in samples from the patient or any secondary or tertiary case. Whenever possible, samples of blood, oral fluid and urine were collected and forwarded to the National Reference Centre Measles, Mumps, Rubella to further confirm the diagnosis by measles virus genotyping and to investigate transmission chains.

\section{Results}

As of 31 October 2010, 13 primary cases who met the case definition had been identified from reports in Baden-Wuerttemberg $(n=9)$, North Rhine-Westphalia $(n=1)$, and Bavaria $(n=3)$. Patients' ages ranged from 9 to 32 years (median: 16.5). Ten cases were female. None of the primary cases reported a history of clinical measles or having received measles virus-containing vaccine. Three cases were hospitalised for two - three days.

All 13 primary cases had travelled to Taizé from their various places of residence, either in youth groups (seven cases), with family (three cases) or a friend (one case). Cases 2 and 3 were persons who arrived in a bus chartered by their youth group. Cases 10 and 11 were siblings who had travelled in a private car with their parents. None of the other cases had shared the same means of transportation (e.g. charter bus, private car, hitchhiking), excluding a common source of exposure during outbound or return travel. Distances of the 
cases' travel to Taizé by road varied between $390 \mathrm{~km}$ and $740 \mathrm{~km}$ (median: $520 \mathrm{~km}$ ).

Periods of sojourn at Taizé ranged from six days to five weeks (the longest stay being for a volunteer helper, Case 4). Ten cases stayed for eight or nine days, mostly from Sunday to Sunday, which are the arrival and departure days recommended by the Community. Accommodation was in six - eight-bed dormitories (five cases) shared with youths from the same or other travel groups, in a family room (one case), or in their own tents that they brought with them (five cases); details of accommodation remain unknown for two cases.

Interviewed cases reported to have participated in a broad range of scheduled activities such as common prayers and meals, discussion groups, practical assignments, thematic workshops and informal gatherings at a common area, providing a picture of multiple possibilities for encounters with other persons in attendance. All primary cases were present on at least one weekend day between Friday 27 and Sunday 29
August 2010, and on a various number of days before or after this period (Figure 1).

Eight of 13 primary measles cases did not cause secondary measles virus infections. Five primary cases resulted in 17 secondary cases (age range: $2-47$ years, median: 15 ) and seven tertiary cases (age range: 5-18 years, median: 13). The persons affected were family members, friends and schoolmates, predominantly of a similar or younger age. In total, 37 measles cases could be attributed to this outbreak (Figure 2).

One 15-year-old secondary case had received a single dose of measles virus-containing vaccine in 2000. All other primary, secondary and tertiary cases were reported as unvaccinated.

The diagnosis of measles was laboratory confirmed by enzyme-linked immunosorbent assay (ELISA) in 10 primary cases by IgM or by a rise in IgG antibody level. Laboratory confirmation was obtained for two secondary measles cases who had been in contact with two clinical primary cases during the infectious period upon return. One primary measles case was

\section{FIGURE 1}

Dates of sojourn at Taizé, France, and of symptom onset of primary measles cases, Germany, August - September 2010 $(\mathrm{n}=13)$
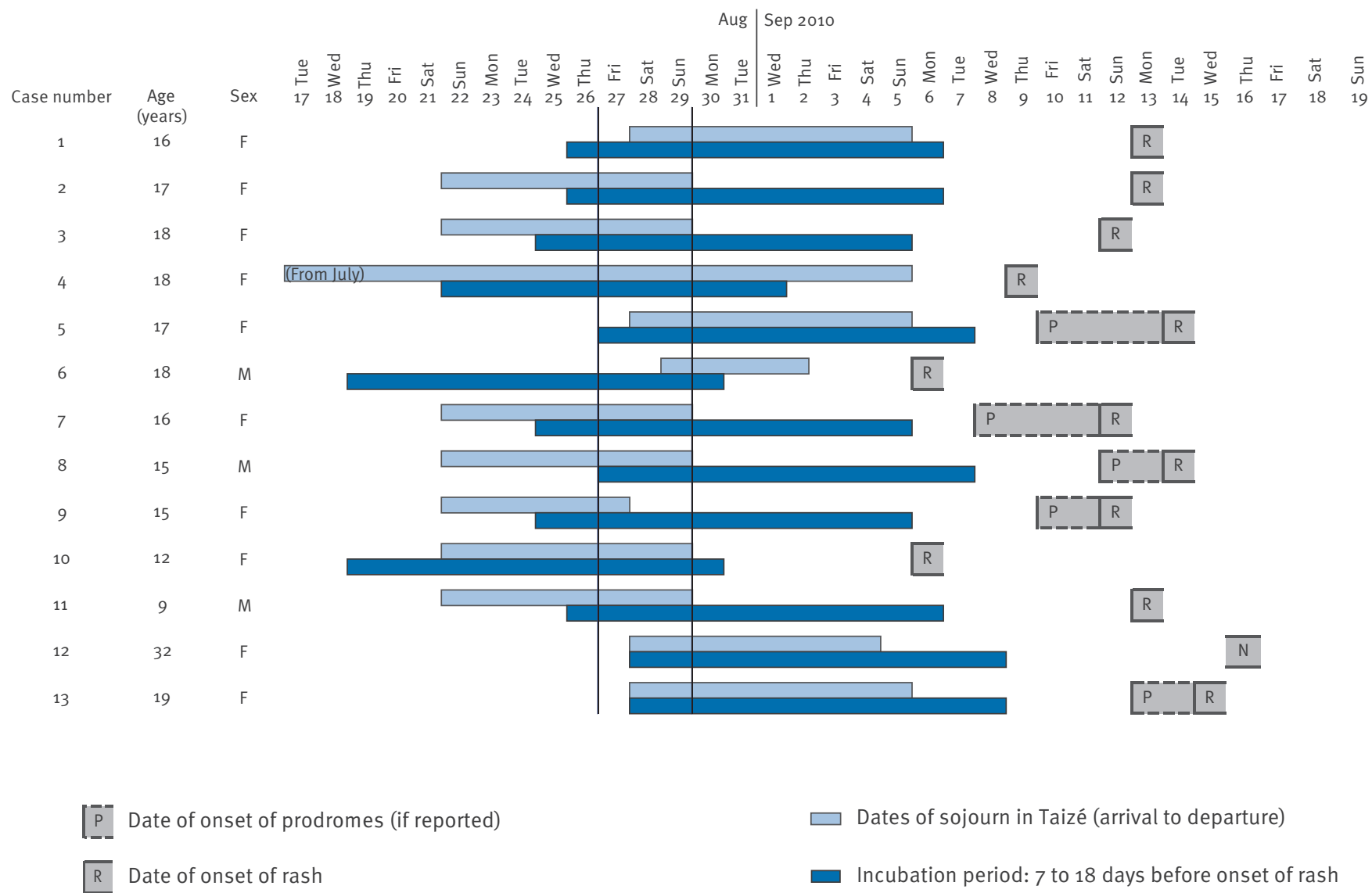

$\overline{\mathrm{N}}$ Date of measles notification, assumed as one day after onset of rash 
diagnosed clinically. Two primary cases were not laboratory confirmed, but both were the infection source of

\section{FIGURE 2}

Geographical spread of measles cases, Germany, September - October $2010(n=37)$

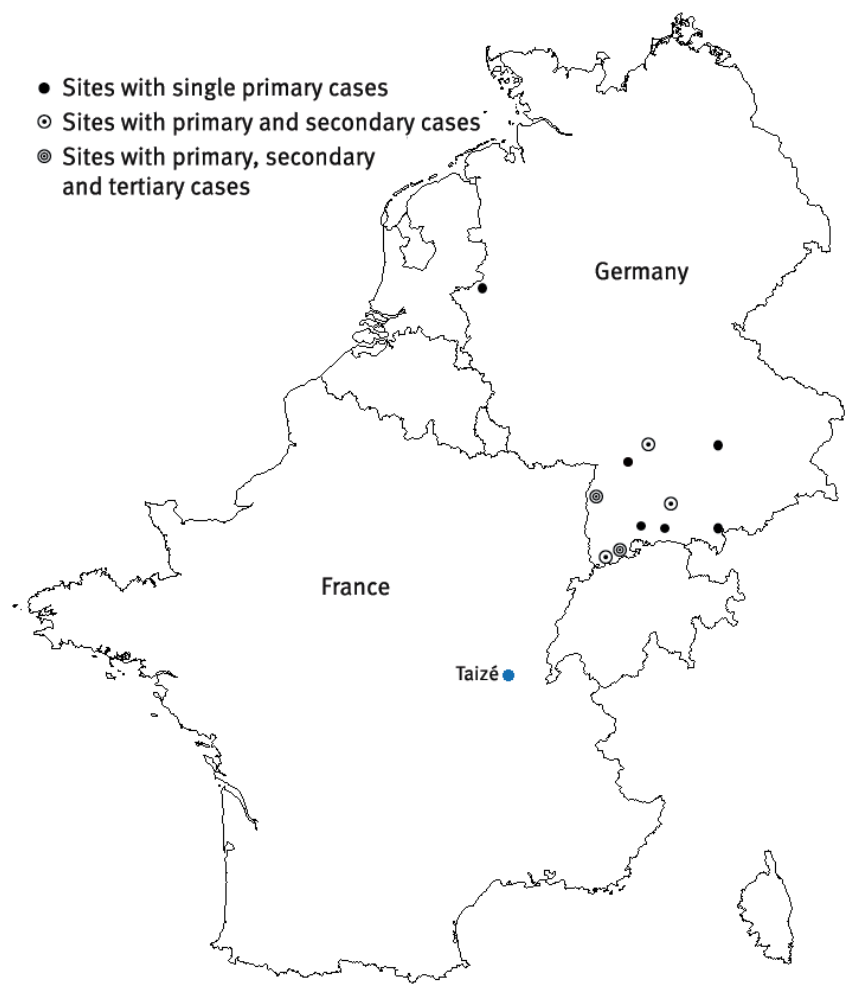

at least one secondary case with laboratory-confirmed measles.

The measles viruses isolated in Germany from midSeptember until end of October 2010 were compared with prototypic measles viruses representing the predominant D4 sub-variants in western Europe.

Genotyping was performed for Case 1 (VillingenSchwenningen.DEU/37.10) who had been infected in Taizé and for five secondary cases who had been in contact with either Case $3(n=3)$, Case $6(n=1)$ or Case $8(n=1)$ (Figure 3). Phylogenetic analysis was based on a 456-nucleotide sequence encoding the C-terminus of the measles virus Nucleocapsid-protein. All five cases analysed showed the genotype $\mathrm{D}_{4}$ variant 'D4-Manchester' (MVs/Manchester.GBR/10.09[D4], GenBank accession number: GQ370461).

This suggests that the German cases with a suspected link to the meetings in Taizé belong to the same chain of measles virus transmission. Occurrence of measles virus variant $\mathrm{D}_{4}$-Manchester in western and central parts of Europe from 2008 onwards is reported in the GenBank and the MeaNS database. In 2010, this variant was identified several times in France [5].

\section{Discussion}

In Europe, measles outbreaks have been reported to occur in, among other settings, anthroposophical communities [6], minority populations [7] and unvaccinated

\section{FIGURE 3}

Phylogenetic relationships within measles virus genotype D4, measles outbreak, Germany, September - October $2010(\mathrm{n}=6)$

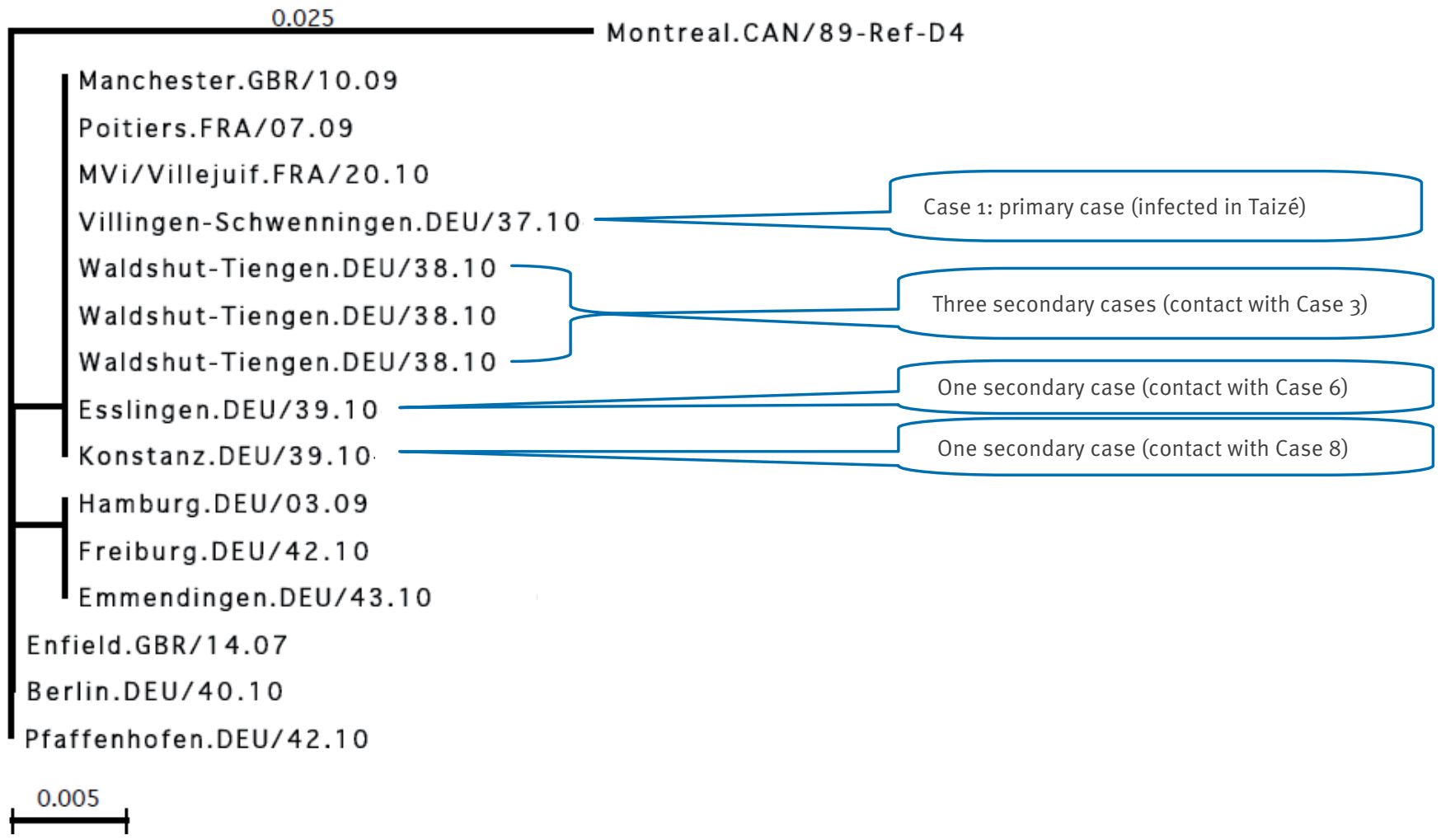

The genotypes of the virus from the six cases are indicated in boxes. The other genotypes listed are shown for comparison (from GenBank). 
preschool children [8]. In the United States where elimination has been achieved, the challenges to maintain elimination are considered to include outbreaks of measles resulting from travel to countries where measles is still endemic, frequent international travel and persons who remain unvaccinated because of personal belief [9].

This multilocal outbreak illustrates the risk of exposure to measles virus at mass gatherings while measles elimination has not yet been achieved. In addition, it underlines the potential for long-distance spread of measles virus by mobile, non-immune adolescents and adults. We consider it likely that additional measles cases may have occurred among persons who visited Taizé at the end of August 2010 and returned to other destinations, where the possible source of exposure went unnoticed or remains unpublished.

In 2008 , the nationwide measles vaccination coverage for German children at the time of their school entry examination (five to six years) was $95.9 \%$ for the first dose, and $89 \%$ for the second dose, with considerable geographical variation [10]. While measles vaccination coverage among younger children is on the rise, it should not be forgotten that immunisation coverage in older age cohorts may not yet have reached levels required for measles elimination.

In conclusion, measles may be reintroduced by returning travellers or visitors who have been infected with the virus. Public health policy should recognise the importance of proactive information of adolescents and young adults in order to address gaps in individual measles immunity, and by encouraging the vaccination of non-immune adolescents and young adults.

\section{Acknowledgements}

We thank the staff of local public health offices in Ansbach, Calw, Esslingen, Kempten, Konstanz, Neckar-OdenwaldKreis, Offenburg, Ravensburg, Villingen-Schwenningen, Waldshut-Tiengen and Wesel, for detailed investigations of measles notifications and measles virus sampling. Our thanks also to patients and their caregivers, for their contribution of information and diagnostic samples for viral genotyping. Special thanks to members of the Taizé Community and the Sisters of Saint-Andrew, Ameugny, France, for most valuable cooperation in the epidemiological investigation.

\section{References}

1. Pfaff G, Mezger B, Santibanez S, Hoffmann U, Maassen S, Wagner U, et al. Measles in south-west Germany imported from Switzerland - a preliminary outbreak description. Euro Surveill. 2008;13(8):pii=8044. Available from: http://www. eurosurveillance.org/ViewArticle. aspx?Articleld $=8044$

2. Bätzing-Feigenbaum J, Pruckner U, Beyer A, Sinn G, Dinter A, Mankertz A, et al. Spotlight on measles 2010: Preliminary report of an ongoing measles outbreak in a subpopulation with low vaccination coverage in Berlin, Germany, JanuaryMarch 2010. Euro Surveill. 2010;15(13):pii=19527. Available from: http://www.eurosurveillance.org/ViewArticle. aspx?Articleld $=19527$
3. Schmid D, Holzmann H, Abele S, Kasper S, König S, Meusburger S, et al. An ongoing multi-state outbreak of measles linked to non-immune anthroposophic communities in Austria, Germany, and Norway, March-April 2008. Euro Surveill. 2008;13(16):pii=18838. Available from: http://www. eurosurveillance.org/ViewArticle.aspx?Articleld $=18838$

4. Robert Koch Institute (RKI). Masernerkrankungen nach Aufenthalt in Taizé, Frankreich, August-September 2010. [Measles after visit to Taizé, France, August-September 2010]. Epid Bull. 2010;38:390. German. Available from: http://edoc. rki.de/documents/rki_fv/reks9drSqBeZg/PDF/264lkliTPE42P6. pdf

5. Parent du Châtelet I, Antona D, Freymuth F, Muscat M, Halftermeyer-Zhou F, Maine C, et al. Spotlight on measles 2010: Update on the ongoing measles outbreak in France, 2008-2010. Euro Surveill. 2010;15(36):pii=19656. Available from: http://www.eurosurveillance.org/ViewArticle. aspx?Articleld $=19656$

6. van Velzen E, de Coster E, van Binnendijk R, Hahné S. Measles outbreak in an anthroposophic community in The Hague, The Netherlands, June-July 2008. Euro Surveill. 2008;13(31):pii=18945. Available from: http://www. eurosurveillance.org/ViewArticle.aspx?Articleld=18945

7. Pervanidou D, Horefti E, Patrinos S, Lytras T, Triantafillou $E$, Mentis A, et al. Spotlight on measles 2010: Ongoing measles outbreak in Greece, January-July 2010. Euro Surveill. 2010;15(30): pii=19629. Available from: http://www. eurosurveillance.org/ViewArticle.aspx?Articleld=19629

8. Groth C, Böttiger BE, Plesner A, Christiansen AH, Glismann $\mathrm{S}$, Hogh B. Nosocomial measles cluster in Denmark following an imported case, December 2008-January 2009. Euro Surveill. 2009;14(8):pii=19126. Available from: http://www. eurosurveillance.org/ViewArticle.aspx?Articleld=19126

9. Parker Fiebelkorn A, Redd SB, Gallagher K, Rota PA, Rota J, Bellini W, et al. Measles in the United States during the postelimination era. J Infect Dis. 2010;202(10):1520-28.

10. Robert Koch Institute (RKI). Impfquoten bei den Schuleingangsuntersuchungen in Deutschland 2008. [Vaccination rates at school entry examinations in Germany 2008]. Epid Bull. 2010;16:137-40. German. Available from: http://www.rki.de/cln_169/nn_199624/DE/Content/Infekt/ EpidBull/Archiv/2010/16__10,templateld=raw, property=public ationFile.pdf/16_10.pdf 